\title{
Low Dose Computed Tomography of the Whole Body
}

National Cancer Institute

\section{Source}

National Cancer Institute. Low Dose Computed Tomography of the Whole Body. NCI

Thesaurus. Code C137923.

Computed tomography (CT) of the whole body that uses less radiation than a standard $\mathrm{CT}$. 